\title{
The Influence of Contextual-Inquiry Based Worksheet in Water Microbiology Material for Students' Scientific Process Skills in FMIPA UNIMED
}

\author{
Diah Kesumawati \\ Biology Department \\ Postgraduate Program of Universitas \\ Negeri Medan \\ Medan, Indonesia \\ diahk.hartanto@gmail.com
}

\author{
Hasruddin \\ Biology Department \\ Postgraduate Program of Universitas \\ Negeri Medan \\ Medan, Indonesia \\ hasruddin@unimed.ac.id
}

\author{
Mufti Sudibyo \\ Biology Department \\ Postgraduate Program of Universitas \\ Negeri Medan \\ Medan, Indonesia \\ mufti_sudibyo@unimed.ac.id
}

\begin{abstract}
This study aimed to determine the effect of the application of contextual-inquiry based worksheets on students' scientific process skills in the sixth semester of biology education undergraduate students in FMIPA UNIMED. This study used a quasi-experimental method with one dependent variable with 3 (three) classes as sample which are determined by random class. Regular class $A$ got the treatment of applying contextual inquiry worksheets, Extension class A got the treatment of applying PBMP worksheets (pemberdayaan berpikir melalui pertanyaan / empowering thinking through questions), and Extension class $B$ (control) got treatment for applying conventional worksheets. The research instrument was a list of description questions to test scientific process skills. Data analysis techniques used covariate analysis (ANACOVA) at a significant level $\alpha=0.05$ with SPSS 23 for Windows. The results showed that there was a significant effect of among the scientific process skill results, namely inquiry-based worksheets (83.48 \pm 6.477), contextual PBMP (78.96 \pm 5.389), conventional $(78.05 \pm 6.904)$ on with $F=4.364, P=0.016$. The results of this study stated that contextual inquiry worksheets can improve students' scientific process skills.
\end{abstract}

Keywords: Scientific Process Skills; Microbiology; Student Worksheet; Contextual Inquiry.

\section{BACKGROUND}

Law Number 20 of 2003 concerning the National Education System states that national education has the function of developing capabilities and shaping the character and destiny of a dignified nation in the context of intellectual life of the nation. Education aims to develop the potential of students to become human beings who believe and devote to God Almighty, noble, healthy, knowledgeable, capable, creative, independent and become citizens who are democratic and responsible (Trianto, 2012: 1)

One of the problems facing the world of education is the problem of weak learning processes (Yamin and Maisarah, 2012). In learning, children are less encouraged to develop thinking skills. The learning process in the classroom is directed to the child's ability to memorize information, the child's brain is constantly accustomed to remembering and storing various information without being required to link it with daily life (Sanjaya, 2011). Problems of the learning process that takes place continuously during learning will result in stunted brain development, low thinking ability and decreased student attitudes towards learning.

The low thinking ability of these students can be seen from the scientific abilities of Indonesian children, where the scores achieved by Indonesian students are still low. This is in accordance with the results of the research program for the International Student Assessment (PISA) in 2003, 2006, 2009 stating that the ability of students in science is still very alarming. The level of scientific literacy of students is ranked 57 th out of 65 participating countries with a score of 383 and this score is below the standard average of the PISA (OECD, PISA 2009 Database). This means that the Indonesian students are allegedly only able to remember scientific knowledge based on simple facts (Sulistiyo, 2012).

Microbiology courses are included in the scientific and skills courses (MKK). Ministry of National Education Number 232 / U / 2000 Chapter 1 article 1 (8) states that scientific and skills courses (MKK) are a group of study materials and lessons aimed primarily at providing a certain foundation for mastery and skills. By improving the model, appropriate learning media in presenting water analysis materials and their application are expected to provide meaningful links to students with real situations and can encourage students to work together, which in turn can improve science process skills.

Contextual Teaching and Learning is a learning concept that helps lecturers link material taught with real-world situations of students and encourages students to make connections between the knowledge they have and their application in their daily lives, involving seven main components of effective learning, namely: construct (contructivism), asking (questioning), finding (inquiry), learning group (learning comunity), forming (modeling), and actual marking (authentic assessment) (Jumadi, 2003). 
Contextual learning according to Muslich (2008) is not exclusive, but can be combined with other learning models, such as discovery, process skills, experiments, demonstrations, discussions, and others. One learning model that is seen as in line with the principle of a contextual approach is the inquiry model. The finding component (inquiry) is a core activity of learning with a contextual approach.

Scientific process skills can be obtained by inquiry-based learning, so students are expected to gain a deeper understanding of themselves and the environment (BSNP, 2006). Puskur (2007) revealed similar things, namely the process of learning biology including microbiology should be carried out in scientific inquiry (scientific inquiry) to foster the ability to think, work, and be scientific and communicate some important aspects of life skills, as well as enhance students' understanding to integrate concepts that they already knew about the events they observed in the laboratory (Mustachfidoh et al, 2013).

An alternative to find out the presence or absence of bacteria found in the water, learning is needed through practicum. Curriculum demands that learning meet the alignment of the three domains (cognitive, affective, and psychomotor) in developing products, processes, attitudes and equipping science learning. This can all be realized with learning activities that are equipped with a Student Worksheet (Lembar Kerja Mahasiswa / LKM). LKM is a worksheet for students that can be carried out experimentally or nonexperimentally to facilitate understanding of the concepts of the subject matter being taught. The nature of learning science is not enough just to remember and understand the concepts discovered by scientists. But what is very important is the habit of scientific behavior in finding concepts that are carried out through experiments / practicums and scientific research. According to the Ministry of National Education (2004) "The main objective of Student Worksheets (LKM) is to train students to work according to scientific procedures in order to gain knowledge, skills and scientific value".

In previous studies, such as the research that has been done, the application of LK can provide better results. This is shown by the results of research Ni'mah (2016), namely the application of LK can improve science process skills. Denisa (2012) the application of student worksheet and torsion media can improve student learning outcomes.

One effort to overcome these problems is that by looking at the application of LK that is adapted to be guided by certain learning models, so that it not only empowers cognitive knowledge, but can empower other competencies such as science process skills, scientific attitudes, and high-level thinking of students. With the Student Worksheet (Lembar Kerja Mahasiswa / LKM) will make students more active and practice science process skills.

\section{MATERIALS AND METHODS}

\section{A. Research Design}

Data analysis techniques used in this study were descriptive analysis techniques and inferential analysis. Description analysis technique was used to describe the research data including the mean, median, mode, standard deviation variants, minimum values and maximum values. The data was then presented in the form of a frequency distribution table using the Sturges reference in the form of a Histogram.

\section{B. Sample}

The population in this research were all undergraduate Biology students which were totaling 7 classes and sum of 180 students, at the Faculty of Mathematics and Natural Sciences, Universitas Negeri Medan (UNIMED) in Microbiology subject. The sample in this research were only 3 classes which were selected by cluster random sampling.

\section{Instruments}

Inferential analysis techniques were used to test hypotheses. Before testing hypotheses, a prerequisite test was carried out on the data collected by testing normality and homogeneity. Normality test was carried out to determine whether the data was normally distributed, normality of data was needed to determine the testing of data to be investigated, namely at the beginning and end of learning. Manually, the normal variable criterion is if 1 count was equal to or greater than the value of 1 table (with an error rate of 0.05 ). The formula used for the Normality test was Kolmogorov-Smirnov using the SPSS 23 program for windows.

Homogeneity test was appointed to find out whether all three distributions in the experimental and control class groups had the same variance or not. Homogeneity test was performed using the Levens Test approach on the SPSS 23 for windows program

\section{RESULTS AND DISCUSSION}

\section{A. Results}

The results of the applying contextual inquiry worksheets, as well as contextual PBMP worksheets (empowerment of thinking through questions) for the pretest of science process skills can be seen in TABLE I.

TABLE 1. DESCRIPTIVE ANALYSIS OF PRETEST DATA IN SCIENTIFIC PROCESS SKILLS

\begin{tabular}{ccccc}
\hline Worksheet & $\begin{array}{c}\text { Minimum } \\
\text { Value }\end{array}$ & $\begin{array}{c}\text { Maximum } \\
\text { Value }\end{array}$ & Mean & $\begin{array}{c}\text { Standard } \\
\text { Deviation }\end{array}$ \\
\hline $\begin{array}{c}\text { Contextual } \\
\text { Inquiry }\end{array}$ & 65 & 89 & 75.85 & 5,655 \\
\hline $\begin{array}{c}\text { Contextual } \\
\text { PBMP }\end{array}$ & 65 & 85 & 76.08 & 4,329 \\
\hline Conventional & 63 & 89 & 76.23 & 6,590 \\
\hline
\end{tabular}

TABLE 1 shown that the results of the pretest students in the experimental class I are learned with the contextual inquiry worksheet the highest grade was 89 and the lowest grade was 65 , while the average grade and standard deviation were 75.87 \pm 5.655. Contextual PBMP worksheets (empowerment of thinking through questions) as experimental class II results of the pretest showed the highest grade of 85 and the lowest 
grade of 65 , while for the average grade and standard deviation of $76.08 \pm 4.329$. Conventional worksheets as the control class showed the highest pretest grade of 89 and the lowest grade was 63, while for the average grade and standard deviation of $76.23 \pm 6.590$.

In addition to the descriptive analysis above, the prerequisite test results for the hypotheses studied were normality test with Kolmogorov-Smirnov test and homogeneity test with Leven's Test. To test the normality of the scientific process skills pretest can be seen in TABLE II.

TABLE II. KOLMOGOROV-SMIRNOV NORMALITY TEST FOR PRETEST IN SCIENTIFIC PROCESS SKILLS

\begin{tabular}{ccc}
\hline Learning Models & Statistical Tests & Significance \\
\hline Contextual Inquiry & 0.115 & 0.197 \\
\hline Contextual PBMP & 0,129 & 0,200 \\
\hline Conventional & 0,151 & 0,200 \\
\hline
\end{tabular}

From the results of the normality test above with the Kolmogorov-Smirnov test, it can be concluded that the initial ability data of the science process skills test in the contextual inquiry class had a data distribution of normally distributed data with a significant 0.197> 0.05. Furthermore, the contextual PBMP class is $0.200>0.05$ and the control class was taught with conventional worksheets with a significance of 0.200 which is significantly greater than 0.05 , which means that the data distribution is normally distributed.

Data on the results of the science process skills posttest on the application of the contextual inquiry worksheet, contextual PBMP and conventional worksheet can be seen in TABLE III.

TABLE III. DESCRIPTIVE ANALYSIS OF POSTTEST DATA IN SCIENTIFIC PROCESS SKILLS

\begin{tabular}{ccccc}
\hline Worksheet & $\begin{array}{c}\text { Minimum } \\
\text { Value }\end{array}$ & $\begin{array}{c}\text { Maximum } \\
\text { Value }\end{array}$ & Mean & $\begin{array}{c}\text { Standard } \\
\text { Deviation }\end{array}$ \\
\hline $\begin{array}{c}\text { Contextual } \\
\text { Inquiry }\end{array}$ & 75 & 94 & 4,292 & 85.70 \\
\hline $\begin{array}{c}\text { Contextual } \\
\text { PBMP }\end{array}$ & 75 & 91 & 4,378 & 83.00 \\
\hline Conventional & 75 & 93 & 5,387 & 82.55 \\
\hline
\end{tabular}

The results of descriptive analysis of the scientific process skills posttest in contextual inquiry class obtained the highest score of 94 and the lowest score of 75 with an average and standard deviation of $85.70 \pm 4.292$. In the contextual PBMP class the results of descriptive analysis obtained the highest score of 91 and the lowest score of 75 with an average score and the standard deviation of $83.00 \pm 4.378$. For conventional class (control) the results of descriptive analysis obtained the highest score of 93 and the lowest score of 75 with an average and standard deviation of $82.55 \pm 5.387$.

After the descriptive analysis was performed, then the prerequisite test for the scientific process skills in posttest, namely the normality test with Kolmogorov-Smirnov can be seen in TABLE IV.
TABLE IV. KOLMOGOROV-SMIRNOV NORMALITY TEST FOR POSTTEST IN SCIENTIFIC PROCESS SKILLS

\begin{tabular}{ccc}
\hline Learning Models & Statistical Tests & Significance \\
\hline Contextual Inquiry & 0,121 & 0,143 \\
\hline Contextual PBMP & 0,110 & 0,200 \\
\hline Conventional & 0,131 & 0,200 \\
\hline
\end{tabular}

From the Kolmogorov-Smirnov normality test on the application of contextual inquiry worksheets obtained the distribution of normally distributed data with a significant value of $0.143>0.05$. In the experimental class II, it was also obtained the distribution of posttest data for scientific process skills with normal distribution with a significant value of $0.200>0.05$ as well as the control class with a significant value of $0.200>0.5$. For the homogeneity test with the Leven's Test, a significant value of $0.252>0.05$ was obtained, which means that the initial test of science process skills had a homogeneous variant.

The results of research data processing showed that the application of contextual inquiry worksheets, PBMP (empowerment of thinking through questions) and conventional had a significant influence on the scientific process skills of UNIMED students on Water Analysis material. Based on the results of research on scientific process skills tests the average score of students in Experiment I class of 85.70, Experiment II class of 83.00 and in the control class of 82.55. The data above shown that the class with the contextual inquiry worksheet had a higher average score than the other classes. To see more clearly the effect of each worksheet on students' scientific process skills can be seen in Figure 1.

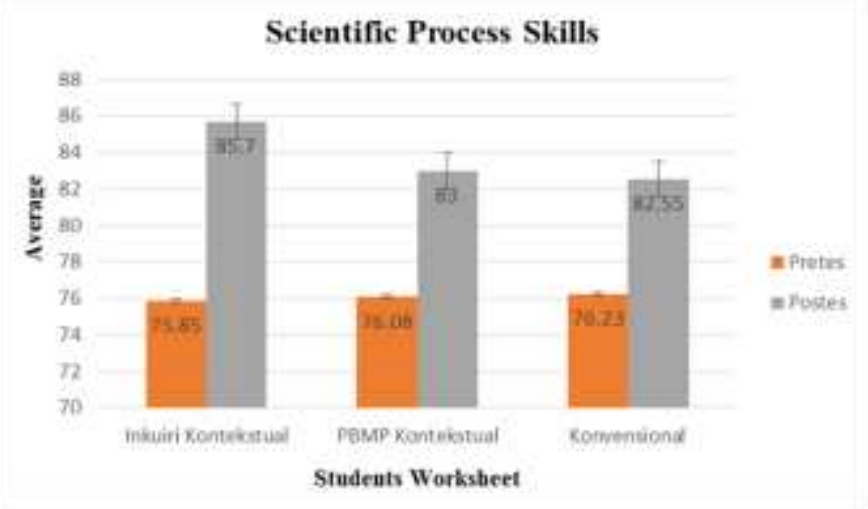

Fig. 1. The Effect of Student Worksheets on Students' Scientific Process Skills

\section{B. Discussion}

This means that students' scientific process skills taught with contextual inquiry worksheets were much better, because the teacher starts this learning by referring to the directed steps by fostering a responsive learning climate or climate.

Concentrate the ability of students to move using their ability to solve problems as an effort to develop mentally through the process of thinking, then students are required to make a hypothesis formulation of a problem that refers to 
solid thinking so that the hypothesis can be rational and logical to the extent that is by describing the findings obtained are based on the results of testing hypotheses from real problems of life with inquiry skills (scientific process skills) forming better student concepts and lasting knowledge.

\section{CONCLUSION}

The results of the research data showed that there was an influence on the application of (1) the contextual inquiry worksheet with an average of 85.70, (2) PBMP (empowerment of thinking through questions) with an average of 83.00 and (3) Conventional with an average an average of 82.55 . had a significant influence on the scientific process skills of UNIMED students in the Water Analysis / Water Microbiology material.

\section{ACKNOWLEDGMENT}

The author expresses the great gratitude to the supervisors: Dr. Hasruddin, M.Pd. and Dr. Mufti Sudibyo, M.Si. who have provided constructive guidance and advice during this research.

\section{REFERENCES}

[1] BSNP. 2006. Standar Isi: Jakarta: Departemen Pendidikan Nasional.

[2] Depdiknas. 2006. Kurikulum Tingkat Satuan Pendidikan. Jakarta: Departemen Pendidikan Nasional. Jakarta.
[3] Muslich, M. 2008. KTSP Pembelajaran Berbasis Kompetensi dan Kontekstual. Jakarta: Bumi Aksara.

[4] Mustachfidoh, Swasta. I. B. J., dan Widiyanti , N. L. P. M. 2013. Pengaruh Model Pembelajaran Inkuiri Terhadap Prestasi Belajar Biologi Ditinjau Dari Intilegensi Siswa SMA Negeri 1 Srono. E-Journal Program Pascasarjana Universitas Pendidikan Ganesha Program Studi Pendidikan IPA.

[5] Ni'mah, S. 2016. Lembar Kerja Mahasiswa Berbasis Inkuiri Terbimbing untuk Meningkatkan Keterampilan Proses Sains Mahasiswa. Lentera Jurnal Ilmiah Kependidikan. 11 (2) : 60-65.

[6] OECD. 2013. PISA 2012 Result: What Students Know and can DoStudent Performance in Mathemathics, Reading and Science (Volume I). PISA: OECD Publishing.

[7] PISA. 2000. The PISA 2000 Assesment of Reading Mathematical and Scientific Literacy. (Online)

[8] Puskur. 2007. Panduan Pengembangan Pembelajaran IPA. Jakarta: Balitbang

[9] Sanjaya, W. 2011. Strategi Pembelajaran Berorientasi Standar Proses Pendidikan. Jakarta: Kencana Pernada Media Group

[10] Sulistiyo. 2012. Refleksi Akhir tahun 2012 pengawas besar PGRI. www.pgri.or.id. Diakses 20 Februari 2018.

[11] Trianto. 2012. Mendesain Model Pembelajaran Inovatif-Progresif Surabaya: Kencana Prenada Media Group.

[12] Yamin, M. \& Maisah. 2012. Orientasi Baru Ilmu Pendidikan. Jakarta: Referensi. 